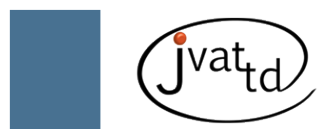

\title{
A new scenario of bioprospecting of Hymenoptera venoms through proteomic approach
}

\author{
Santos LD (1), Pieroni M (2), Menegasso ARS (3), Pinto JRAS (3), Palma MS (3)
}

(1) Center for the Study of Venoms and Venomous Animals, São Paulo State University (UNESP - Univ Estadual Paulista), Botucatu, São Paulo State, Brazil; (2) University of Sorocaba (UNISO), Sorocaba, São Paulo State, Brazil; (3) Center of Study of Social Insects, Department of Biology, Institute of Biosciences, São Paulo State University (UNESP - Univ Estadual Paulista), Rio Claro, São Paulo State, Brazil.

\begin{abstract}
Venoms represent a huge and essentially unexplored reservoir of bioactive components that may cure diseases that do not respond to currently available therapies. This review select advances reported in the literature from 2000 to the present about the new scenario of Hymenoptera venom composition. On account of new technologies in the proteomic approach, which presents high resolution and sensitivity, the combination of developments in new instruments, fragmentation methods, strategic analysis, and mass spectrometry have become indispensable tools for interrogation of protein expression, molecule interaction, and post- translational modifications. Thus, the biochemical characterization of Hymenoptera venom has become a major subject of research in the area of allergy and immunology, in which proteomics has been an excellent alternative to assist the development of more specific extracts for diagnosis and treatment of hypersensitive patients to Hymenoptera venoms.
\end{abstract}

Key words: hymenoptera, venoms, allergens, phospholipase A1, wasp venom antigen 5, hyaluronoglucosaminidase, mass spectrometry, proteomics.

\section{INTRODUCTION}

Several venomous organisms such as reptiles, fish, amphibians, mammals, starfish, sea urchins, cone snails, octopi, nemertines, arachnids, insects, myriapods, and some cnidarians are the target of numerous studies in toxinology for their biotechnological and therapeutic potential (1).

Animal-based medicinal products are involved in global trades that worth billions of dollars per year (2). The World Health Organization already observed that the study of traditional medicines through bioprospecting had found several pharmaceutical compounds, $11.1 \%$ of them were obtained from plants, and 8.7\% from animals. Moreover, of the 150 prescription drugs currently in use in the United States of America, 27 have animal origin (3). After a bradykinin-potentiating peptide was isolated - from the snake venom of the Brazilian Bothrops jararaca in the 1950s - and used to develop the first commercial angiotensin I-converting enzyme (ACE) inhibitor for the treatment of renovascular hypertension, various venom compounds have been investigated as natural sources of more specific/efficient pharmaceutical products $(4,5)$.

In the early 1980s, a non-local anesthetic drug was obtained from a Conus maguns cone snail peptide - $\omega$-conotoxin M-VII-A, an N-type calcium channel blocker. The US Food and Drug Administration (FDA) approved the production of a synthetic peptide of a conotoxin, ziconotide, under the trade name Prialt ${ }^{\oplus}$. The ziconotide molecule is used unmodified from the creature's chemistry to treat chronic pain (6). Several studies have investigated specific animal toxins in order to find alternative therapies to various disorders that affect signaling transduction such 
as Alzheimer's disease (7). Similarly, in previous studies, researchers showed that the venom of solitary wasps, including Anoplius samariensis and Pseudagenia maculifrons, may be useful not only for basic neuroscience research but also for the development of therapeutic agents against neurological disorders (8).

Regarding the development of drugs for the treatment of patients sensitive to Hymenoptera venoms, the allergen-specific immunotherapy is highly effective and recommended for patients with a specific Hymenoptera sting anaphylaxis history. However, effective immunotherapy procedures can be hindered by frequent crossreactions to venoms of different Hymenoptera species, due to difficulties in identifying the responsible species. Thus, a better understanding of the composition of Hymenoptera venoms is a rich subject for many researchers in the allergy and immunology area.

\section{WHY STUDY HYMENOPTERA VENOMS?}

The venom from social Hymenoptera (wasps, bees and ants) is an important defensive weapon. Thus, stinging events involving wasps, honeybees and ants are frequent worldwide and immediate hypersensitivity reactions, such as anaphylaxis, comprise a global cause of death. Moreover, serious envenomations may kill even non-allergic individuals due to multiple stings. The diagnosis of stings by bee, wasp and ant begin from a history of potential contact matched with onset of appropriate clinical signs (9).

It is known that the prevalence of sensitization against Hymenoptera insects was evaluated between 9.3 and $28.5 \%$ in world population (10). Anaphylactic reactions to Hymenoptera stings are not dose dependent or related to the number of stings (11). A single sting may cause a transient local inflammation characterized by pain, redness and swelling in humans (12). Studies showed that the general population present type 1 hypersensitivity reaction, which promotes a series of clinical problems, such as urticaria, itching, malaise, angioedema, chest constriction, diarrhea, abdominal pain, dyspnea, wheezing, weakness, edema, fatigue, dizziness, nausea, fever and unconsciousness as well as drop in blood pressure, collapse, cyanosis, cardiovascular symptoms, up to a life threatening systemic anaphylactic shock $(13,14)$.
Mass stinging events may be life-threatening as a result of venom toxic action when injected in large amounts (4). Systemic reaction is reported to occur in $5 \%$ of the general population (5).

The biochemical characterization of Hymenopteravenom has becomethefocusofmuch research in the area of allergy and immunology, in which proteomic approach has been an excellent alternative to assist the development of more specific extracts for diagnosis and treatment of hypersensitive patients. Currently, allergy immunotherapy specific to Hymenoptera venoms is carried out with crude venom, which usually presents a complex composition, consisting of a large amount of proteins and peptides. It is not possible to estimate the exact composition of venoms and, moreover, natural factors such as degradation heterogeneity of proteins and the source of allergens may hinder procedures for allergy immunotherapy. Thus, such studies can contribute to increase the knowledge about biochemistry of venoms and offer scientific basis for future development of recombinant allergens for diagnostic and therapeutic use against Hymenoptera venom allergies. Figure 1 shows some Brazilian Hymenoptera insects, which were evidenced by Castro and Palma (15).

\section{WHAT IS THE COMPOSITION OF THESE VENOMS?}

Lima and Brochetto-Braga (16) reported that numerous proteins and peptides from wasp and bee venoms had already been identified and characterized by several laboratories throughout the globe. Hymenoptera venoms are constituted of a complex mixture of proteins, a group of polycationic peptides and low molecular mass toxins, in which the proteins are recognized as important allergens $(9,17-20)$. Whereas bee and wasp venoms present are composed of protein and peptides and fire ant venoms, alkaloids and few soluble proteins (11). Hereafter, several recent studies will be explored.

\section{Proteins}

Several major allergens, usually glycoproteins with a molecular weight of 10 to $50 \mathrm{kDa}$, have been identified in venoms of bees, vespids and ants. In general, paper wasp venoms contain phospholipases, antigen 5, hyaluronidase and serinoproteinases. Table 1 presents the classical 
Table 1. Classical proteins isolated from Hymenoptera venoms by basic analytical techniques

\begin{tabular}{|c|c|c|}
\hline Species & Proteins & References \\
\hline Apis mellifera & Phospholipases A & 21 \\
\hline Solenopsis invicta & Sol i I (phospholipase $A_{1}$ ) & 22 \\
\hline $\begin{array}{c}\text { Vespa basalis, } V \text {. orientalis and } V . \\
\text { flaviavitarsus }\end{array}$ & Phospholipase A1/A2 & 23,24 \\
\hline $\begin{array}{l}\text { Vespula maculifrons, Vespula } \\
\text { maculate, and Vespula arenaria }\end{array}$ & $\begin{array}{l}\text { Phospholipases A and } \\
\text { B,hyaluronidase }\end{array}$ & 25 \\
\hline Vespula maculifrons & $\begin{array}{l}\text { Phospholipases A and B, } \\
\text { hyaluronidase, antigen } 5\end{array}$ & 26 \\
\hline Polybia paulista & Phospholipases $A_{2}$ & 27,28 \\
\hline $\begin{array}{c}\text { Vespa basalis, } V . \text { mandarinia and } V . \\
\text { verutina }\end{array}$ & Phospholipases $A_{2}$ & 29 \\
\hline Vespa mandarinia & Phospholipases B & 30 \\
\hline $\begin{array}{l}\text { Dolichovespula maculata, Vespula } \\
\text { squamosa, Polistes exclamans }\end{array}$ & $\begin{array}{c}\text { Phospholipases } A \text { and } B, \\
\text { hyaluronidase and antigen } 5\end{array}$ & 31 \\
\hline Polybia scutellaris & Antigen 5 & 32,33 \\
\hline Solenopsis invicta & Sol i III (antigen 5) & 22 \\
\hline Apis mellifera & Hyaluronidase & 34 \\
\hline Solenopsis invicta & Sol i Il (hyaluronidase) & 22 \\
\hline $\begin{array}{l}\text { Polistes dominulus and Polistes } \\
\text { exclamans }\end{array}$ & Serine protease & 35 \\
\hline $\begin{array}{c}\text { Bombus pennsylvanicus and Bombus } \\
\text { terrestris }\end{array}$ & Serine protease & 36,37 \\
\hline $\begin{array}{c}\text { Bombus pennsylvanicus, } P \text {. dominulus } \\
\text { and P. exclamans }\end{array}$ & Serine protease & 38 \\
\hline Apis mellifera & Serine proteases & 39 \\
\hline
\end{tabular}

proteins found in Hymenoptera venoms by some analytical techniques including liquid chromatography and one electrophoresis.

One of the first studies involving more sophisticated techniques was conducted in the early 1980s. The work showed the complexity of many Hymenoptera venoms and that four proteins were already isolated from Apis mellifera, Polistes fuscatus, $P$. apachus, $P$. metricus, $P$. exclamans, $P$. annularis, Vespula flavopilosa, V. squamosa, V. sulphurea, Dolichovespula maculata and Vespa cabro venoms (40). These pioneering findings first characterized Hymenoptera venom protein profile by two-dimensional sodium dodecyl sulfate polyacrylamide gel electrophoresis (2D SDS-PAGE) in the global literature.
The characterization of Hymenoptera venoms has improved since 2000, when the proteomic method was released by academic institutions, as the extracts utilized in the immunotherapeutic process depended on the composition of such venoms and the comprehension of their action mechanisms.

Probably, the best characterized insect venom is the one from Apis mellifera. However, little is known about the venoms of the Apidae family, which includes social bees, solitary bees and bumblebees (16). Among the stinging Hymenoptera, the venomics of Apis mellifera carnica honeybee was investigated to identify new venom components with allergic potential by Peiren et al. (41) through a proteomic 

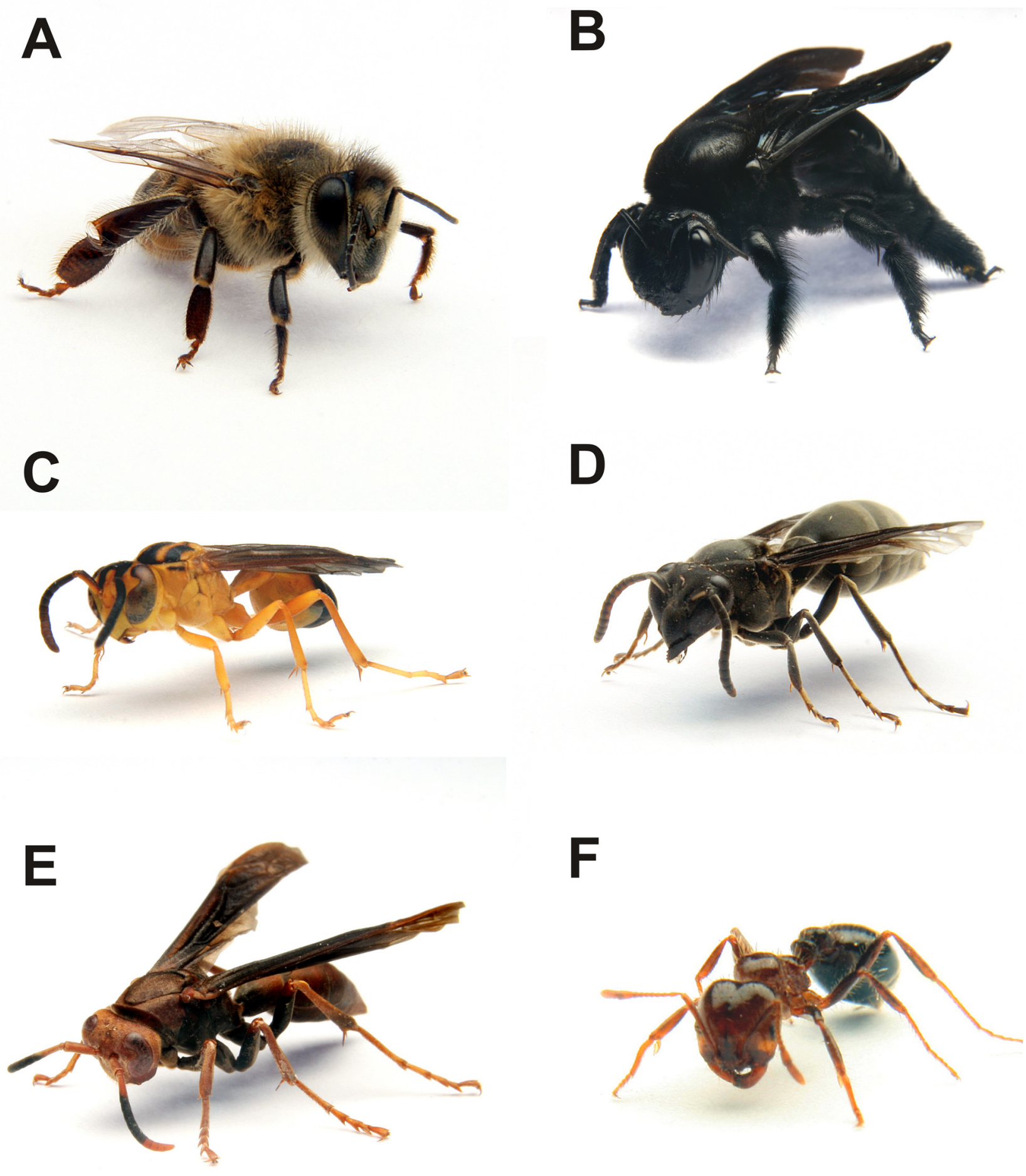

Figure 1. Workers of some Brazilian Hymenoptera insects: (A) Africanized Apis mellifera bee; (B) Bombus sp. bee; (C) Agelaia pallipes pallipes wasp; (D) Polybia ignobilis wasp; (E) Polistes lanio lanio wasp; (F) Solenopsis invicta ant (photos by Martelli Filho).

approach. In that work, honeybee venom was submitted to two-dimensional gel electrophoresis and 49 proteins were elucidated by mass spectrometry (MS), 39 of them were identified as phospholipases $\mathrm{A}_{2}$, hyaluronidases, Api $\mathrm{m} \mathrm{6 \text {, }}$ melitin, secapin and acid phosphatases. For the first time, new venom proteins were described: vascular endothelial growth factor (VEGF) and a protein similar to major royal jelly protein 8 , MRJP-8 and a series of proteins related to the protection of venom against oxidative stress such as superoxide dismutase, glutathione-S- 
transferase sigma 1 isoform $\mathrm{A}$, peroxiredoxin and thioredoxin peroxidase 1 isoform $\mathrm{A}$ were also reported (41). Similarly, Honeybee Genome Sequencing Consortium (42) elucidated the presence of other important proteins in Apis mellifera venom including antigen 5 , proteinases, heat schock proteins (HSP), disintegrins and metalloproteinases.

The understanding of the mechanisms of action of Hymenoptera venoms is a challenging task. Numerous works were carried out to identify the mechanisms that protect honeybee venom gland secretory cells against harmful toxins present in this venom (43). Such studies showed that the venom of honeybee workers is used to defend the colony or themselves when they are exposed to dangers and predators. The proteomic study by Peiren et al. (41) revealed four antioxidant enzymes: thioredoxin peroxidase 1 isoform A (TPX1), CuZn superoxide dismutase (SOD1), peroxiredoxin 2540 (PXR2540) and glutathione-S-transferase sigma 1 isoform A (GSTS1). Although glutathione-S-transferase (GST) has also been associated with xenobiotic detoxification, this protein is known to protect only against oxidative stress. Many proteins involved in other forms of stress were also found in that research. However, the function of these molecules in animal venoms is still unknown (41).

Other important research involved the proteomic analysis of Polybia paulista wasp venom (44). Santos et al. (44) studied 94 out of 225 proteins present in the $P$. paulista wasp venom and, among them, antigen-5, hyaluronidases and PLAs and serine proteinases. Furthermore, novel proteins were reported in wasp venoms including growth factor-like proteins, arginine kinase, superoxide dismutase, $\boldsymbol{\alpha}$-glucosidase, metalloproteinases, zinc metalloproteinasedisintegrins, serine proteinases, proteinase inhibitors, heat shock proteins, Sol i-II and -II like proteins. Through the study, mechanisms of action of Hymenoptera venom were proposed, explaining the action of animal venoms when they are injected into their victims (44). The biochemical characterization of wasp venoms based on protein identification may provide an extensive basis in order to understand their biological mechanisms, which it is an important prerequisite for the development of new drugs.

The proteomic approach also revealed homologues of some common wasp allergens in Polites gallicus and Agelaia pallipes pallipes. In venoms, the classical allergens, such as phospholipase $A_{1}$, antigen 5 , hyaluronidase and serine-protease, were identified and characterized by MS and specific binding to $\operatorname{IgE}(19,45)$.

It is necessary to emphasize the importance of proteomic approach in Hymenoptera venom works. A common aspect among studies is the presence of multiple forms of major allergens in Hymenoptera venom (45-47). Some authors suggest that these proteins occur in different molecular forms in Hymenoptera venoms, since they represent important and extremely common allergens, and they may correspond to either truncated forms of a common larger protein or even isoforms. But why would this happen? Would it be a strategy of the nature to develop alternative molecules to escape from the immune system of their victims?

It is known that prediction of risks of anaphylactic reactions is very important, and the correct diagnosis requires the understanding of the most important allergens present in animal toxins. Recently, the major proteins from Vespula germanica and four additional Vespula species were investigated by proteomic approach. A new hyaluronidase-like protein, proven to be the major component of all Vespula species, was studied by Kolarich et al. (48) through matrixassisted laser desorption ionisation/quadrupoletime of flight mass spectrometry (MALDI-QTOF-MS). Moreover, sequence comparisons of antigen 5 and phospholipases from $V$. vulgaris, $V$. germanica, V. maculifrons, $V$. pensylvanica, $V$. flavopilosa and $V$. squamosa revealed some differences in their amino acid sequences (48).

Recently, many researchers elucidated, by molecular modeling, the tridimensional structure and post-translational modifications of major allergens such as phospholipase $A_{1}$ and hyaluronidase from Polybia paulista venom, hyaluronidase from Vespula vulgaris venom, phospholipase $\mathrm{A}_{2}$ and Api $\mathrm{m} 7$ from Apis mellifera (45, 49-51). Additionally, the differences among allergens from Hymenoptera venoms are the focus of several studies. It was demonstrated that the allergen antigen 5 presents differences among Polistes venoms, mainly in relation to the amino acids sequences of the allergens from the venoms of North American and European Polistes wasps (20). These findings are very important 
to pharmaceutical industries since novel drugs and specific treatments can be improved if these allergens are better understood structurally and their linear and conformational epitopes are identified.

Many studies were performed in order to characterize the venoms of social wasps by using SDS-PAGE and MS. Recently, the identification and characterization of venom proteins of two solitary wasps - Eumenes pomiformis and Orancistrocerus drewseni - elucidated the presence of various immune response-related proteins and antioxidants. It was suggested that solitary wasps might use their own venom to keep their prey fresh to protect it from invasion of microorganisms and physiological stresses (52).

Some works have constructed cDNA libraries of venom glands and, consequently, numerous novel genes were identified, including those that encode venomous proteins of solitary bee venom. The venom gland of Orancistrocerus drewseni wasp was used to determine differential gene expression profiles in the venom gland and sac of solitaries hunting wasp species. A total of 498 expressed sequence tags (EST) were gathered into 205 contigs. Among these data, 115 contigs were similar to proteins with assigned molecular function in the Gene Ontology Database. Most contigs of the study were homologous to genes from Hymenoptera, encoding several proteins as hyaluronidase, phospholipase $\mathrm{A}_{2}$ and zincmetallopeptidases (53).

Few studies have been carried out using ant venom because of the amount of venom in their glands. It is known the venom from fire ants is composed of $90 \%$ of piperidine alkaloids and $10 \%$ of allergenic proteins (54). Studies carried out by Chen et al. $(55,56)$ showed that dialkylpiperidines are characteristic of fire ants of the genus Solenopsis (Hymenoptera: Formicidae). Workers of the black fire ant, S. richteri and S. invicta, produce different stereoisomers of 2,6-dialkylpiperidines. These findings are discussed in relation to the evolutionary significance of these piperidines and their possible biosynthetic pathways in Solenopsis sp. ants. Moreover, the venom proteins of Solenopsis invicta have been the focus of a series of studies, in which three principal allergens were identified (Sol i I, Sol I II and Sol I III) and characterized as phospholipase $\mathrm{A}_{1}$, hyaluronidase and antigen 5, classical allergenic proteins from wasp and bee venoms (20).
The identification of novel allergens and different forms of known ones will be useful in helping to build more complete microarrays of proteins for allergy diagnosis. It may even help contribute to the development of suitable protocols for the expression of recombinant forms of proteins, to be used in the immunotherapy of patients sensitive to wasp venom. Besides, the allergenicity of some venom proteins is probably the most well studied action of stinging incidents perpetrated by social wasps. The identification of individual allergens, as well as their molecular characterization, certainly will contribute to the identification of the whole panel of Hymenoptera venom allergens.

\section{Peptides}

The peptide components of venoms from social Hymenoptera are spread over the molar mass range of 1400 to $7000 \mathrm{Da}$ and together comprise up to $70 \%$ of weight of freeze-dried Hymenoptera venom (57).

In a previous work by Palma (58), the author described how important peptides are in several physiological processes, working as neurotransmitters, hormones, toxins, antibiotics, and defensins since venom peptides act on a wide variety of membrane protein receptors and may interact directly with phospholipids of the plasma/organelle membranes or with cytosolic proteins to regulate their activities.

Several peptides have been described from wasp venoms, including mastoparans, protonectins, chemotactic peptides, kini related peptides (wasp kinins or bradykinin homologue), sylverin and cabrolin (59). Whereas chemotactic peptides recruit macrophages and polymorphonuclear leukocytes near the site of stinging, mastoparans and protonectins were proven to act as mast cell degranulating peptides responsible for histamine release $(12,60)$. Mastoparans present an amphipathic $a$-helical conformation that permits the creation of porin structures in membranes and the release of histamine. Besides, these peptides are assumed to trigger histamine release via G-protein coupled receptor cascades; additionally, regarding the venom proteome, mastoparans are thought to regulate some venom enzymes $(12,60,61)$. It is known that some mastoparans bind to G-protein coupled receptors (GPCRs) that are involved in the activation of different types of basophils, chemotaxis of 
leukocytes, and neurotoxicity $(62,63)$. Several mastoparan and protonectin homologues have been sequenced from different wasp species using Edman degradation and tandem mass spectrometry (MS/MS) (6, 59). Studies have shown that the use of two or more peptides from wasp venoms can potentiate biological activities, for example, the mixture of two (protonectin 1-6 and protonectin) can amplify the activities of mast cell degranulation, LDH releasing from mast cells, and antibiosis (17).

The literature shows that mastoparans, wasp kinins, antimicrobial peptides and myotoxic peptides were identified among the peptides found in social wasp venoms (64-70). Furthermore, it was also reported that some wasp venom peptides provoke myonecrosis and apoptosis, probably involving caspases signalling, which is corroborated by mitochondrial damage and cytokine activation (71).

Regarding bee venom, it is composed of several peptides including melittin, apamin, adolapin, mast-cell degranulating peptide and secapin that were previously characterized and analyzed (16). A novel melittin isoform from Africanized Apis mellifera venom was found to be less hemolytic and to present a less organized secondary structure (72). In this scenario, the use of matrixassisted laser desorption/ionization-time of flight (MALDI-TOF) and nano-electrospray ionization quadrupole time-of-flight (ESI-Q-TOF) mass spectrometry permitted the identification of several peptide sequences including melittin and different breakdown products. Matysiak et al. (73) discovered a new peptide [HTGAVLAGV + amidated (C-term)] in the bee venom, but its function is yet unknown.

Several Hymenoptera venom peptides were evaluated by injecting them into the hind paw of mice (74). The results showed that mellitin (Apis mellifera), polybia-MP-I, N-2-polybiaMP-I (Polybia paulista), protonectarina$\mathrm{MP}-\mathrm{NH} 2$ and protonectarina-MP-OH (Protonectarina sylveirae) produced hyperalgesic and edematogenic effects. These results indicate that these peptides could contribute to better understand about the inflammation process and pain induced by A. mellifera, P. paulista, and $P$. sylveirae venoms (74).

Although social wasps, bee and ants are better known as venom producers, the vast majority of Hymenoptera are solitary wasps. Whereas the social Hymenoptera use their venoms for hunting and defending themselves and their colonies, the solitary wasps use them only to paralyze their prey (75). Therefore, neurotoxic compounds and bioactive substances such as eumenine mastoparan-AF, anoplin, pompilidotoxins and, mainly, bradykinin-related peptides present in the venoms of solitary wasps are responsible for causing long-term and non-lethal paralysis of the prey $(9,53)$.

Several neurotoxic components and antimicrobial peptides have been isolated from solitary wasp venoms. The discovery of venom gland/sac-specific genes has encouraged further studies on biologically active components in the venom of Orancistrocerus drewseni (53). Moreover, philanthotoxins found in the venom of Philanthus triangulum inhibit neuromuscular transmission by blocking postsynaptic glutamate (76).

The venoms of Megascolia flavifrons, Anoplius samariensis, Batozonellus maculiforns, and Cyphononyx dorsaris were proven to contain several kinins that block nicotinic acetylcholine receptors $(8,77-80)$. Furthermore, antimicrobial peptides and mastoparans were found in Anterhynchium flavomarginatum, A. samariensis, and Eumenes rubronotatus (8, 77-83).

Concerning ant venoms, Myr 1 from Myrmecia pilosa wasidentified as an major allergenic product followed by Myr 2, and they may dissociate or be cleaved into minor fragments, such as pilosulin-1 and -2 . Pilosulins, in their turn, were shown to have antimicrobial peptides, hemolysins and histamine release peptides (84).

Other researchers identified and described: poneratoxins that are neuropeptides obtained from the venom of Paraponera clavata ant, ponericins that have hemolytic effects, insecticidal and antimicrobial activities, and ectatomins that are neurotoxins isolated from Ectatomina turbeculatum venom (85-87).

In addition to inflammatory responses, the pilosulins of the venom of jack jumper ant (Mymercia pilosula) were proven to be immunological molecules. New variants of pilosulins were identified in serum samples from patients with a history of jack jumper ant sting allergy. One of these peptides was designated as the minor allergen Myr p 3 according to the International Union of Immunological Societies nomenclature. Although peptidomes are mainly 
characterized via high performance liquid chromatography (HPLC) and mass spectrometry, a gel-based protocol for studying the peptidome of the jack jumper ant was also revealed. Using SDS-PAGE, new disulfide-linked dimmers were identified by comparing non-reduced and reduced/alkylated venom $(12,88)$.

\section{LOW MOLECULAR MASS COMPOUNDS}

Besides proteins and peptides, Hymenoptera venoms present biologically active amines, which are non-peptide components with a variety of pharmaceutical properties (89). Among the low mass compounds are histamine, serotonin, lysine, octopamine, GABA, spermidine, spermine, arginine, acetylcholine and several other molecules (90-92). These toxins are neurotransmitters, agonists and/or antagonists of ion channels (93). Such compounds are used by solitary wasps to modulate neurotransmission in insect prey permitting them to paralysis, since they use their venoms only for active defense (94-97).

Recently, a novel low mass compound was isolated from the venom of the social wasp Polybia paulista and identified as polybioside. Its structure was assigned as 3,4,5-trihydroxy-6(hydroxymethyl)tetrahydro-2H-pyran-2-yl-3(1H-imidazol-4-yl) propanimidate by magnetic resonance and MS protocols. The application of this low mass compound in rat brain, followed by the detection of c-Fos protein expression in some brain regions indicated that the compound is neuroactive in a number of brain areas, causing convulsions in rats, even when peripherally applied (17).

\section{STATE OF THE ART IN HYMENOPTERA VENOM BIOPROSPECTING}

The bioprospecting of novel molecules in the pharmaceutical and biomedical areas employs the proteomics analysis strategy. But what is proteomics? Proteomics is a term that refers to all the proteins expressed by a genome; it involves the identification of proteins in the body and the determination of their role in physiological and pathophysiological functions. Proteomic studies represent onlyasubset of all possiblegene products, since the genetic machine of organisms produces different molecules depending on the genes that will be activated or inhibited at a certain point of time (98). Thus, post-translational modifications or degradation processes that affect protein structure, localization and function are targets of numerous studies in this area, particularly proteolytic degradation products of proteomes that contain disease-specific information (98).

The development of proteomic strategies offered new drug candidates for clinical assays, including the identification of novel biomarkers for disease detection and evaluation of drug adverse effects. Besides the standardization of proteomic methods, the accessibility of proteomic data in public databases has aided research of molecules derived from known genomes, such as Hymenoptera venoms.

The implementation of proteomic approach helped in the discovery of new drugs by using the sensitivity and high-throughput process of modern mass spectrometers. Over the last decade, mass spectrometry has achieved a high status in bioprospecting research since it identifies and characterizes several proteins that would previously have been overlooked. Some types of mass spectrometry equipments are responsible for large-scale investigations and detection of complex structures like post-translational modifications. Other methods such as twodimensional gel electrophoresis, differential gel electrophoresis (DIGE), in gel protein digestion and bioinformatics tools can be useful in proteome analysis since they can identify more specifically drug candidates.

Hymenopteran venoms have been intensively studied and they are subjected to modern venom profiling studies. Originally, crude venom extracts were separated by liquid chromatography and proteins or peptides of interest were further biochemically characterized using bioassays, Edman degradation chemistry, spectroscopy and eventually X-ray crystallography (20). Although these techniques showed to be useful in the initial characterization of venom compounds, they are single compound oriented, time-consuming and little sensitive. Such characteristics contrast sharply with novel profiling techniques like mass spectrometry (12).

The main applications of MS in proteomics are: identification of protein expression, elucidation of protein-protein interactions and confirmation of post-translation modifications. For any MS experiment, it is necessary to select mass spectrometry equipment depending 
on the molecule to be analyzed and the fragmentation analysis method (99). But, what constitutes a mass spectrometry equipment? Mass spectrometers consist of an ion source that transforms the molecules into gas-phase ions, a mass analyzer that separates ionized molecules according to $\mathrm{m} / \mathrm{z}$ ratio, and a detector that records the number of ions at each $\mathrm{m} / \mathrm{z}$ value. The development of soft ionization techniques - including electrospray ionization and matrixassisted laser desorption/ionization - capable of ionizing peptides or proteins revolutionized molecules analysis $(100,101)$.

In the same way, a mass spectrum shows the mass-to-charge ratio $(\mathrm{m} / \mathrm{z})$ of gas-phase ions representing a chemical analysis. The mass spectrum of a sample is a pattern representing the distribution of ions by mass in a sample. However, some molecules cannot be analyzed by mass spectrometry. Depending on their biochemical characteristics, a molecule will not ionize and it will be necessary that the researcher chooses other ionization methods.

Many complete genomes are becoming publicly available with the recent high throughput analytical process and therefore stimulating largescale protein experiments. In a classical bottomup proteomic approach, proteins are obtained by several chemical preparations and separated by 2 D-SDS-PAGE (Figure 2) (102, 103). Then, individual protein spot are excised from gel electrophoresis and proteolytically digested and identified by using peptide mass fingerprinting (PMF) (Figure 3) or/and tandem mass spectrometry (MS/MS or MS2) with database searching algorithms as MASCOT, Profound, ProteinProspector, SEQUEST, for example (104, 105). Multidimensional liquid chromatography combined with modern mass spectrometers is one of new approach in recent proteome researches named shotgun strategies (106). This approach is able to isolate the molecules by liquid chromatography and sequence them by mass spectrometry at the same time, e.g., this strategy is very useful when there is a small amount of sample or the researcher needs to identify minor compounds of the sample.

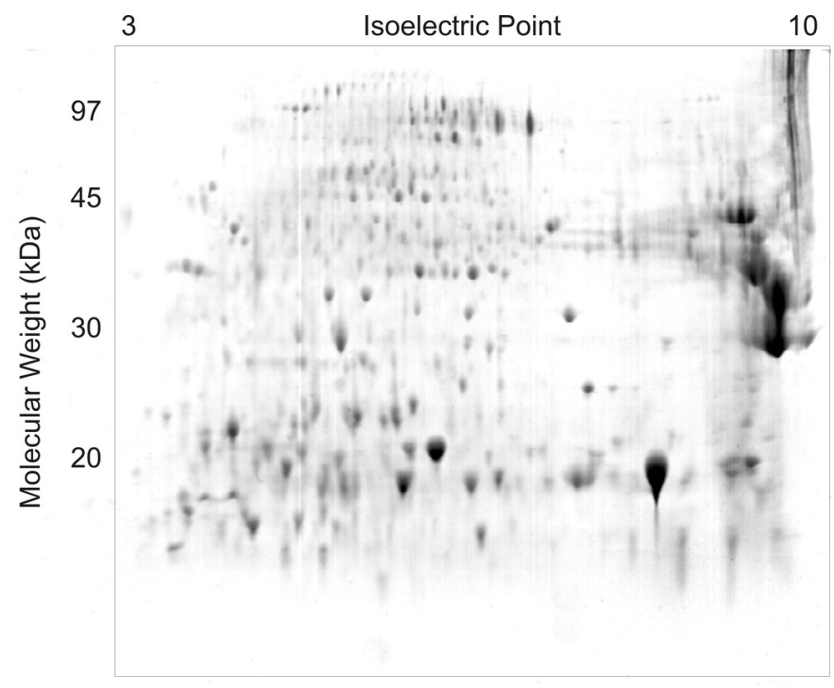

Figure 2. Two-dimensional SDS-PAGE of Polybia paulista wasp venom by Santos et al. (44). The proteins of this venom were separated based on two biochemical properties: charge and molecular mass.

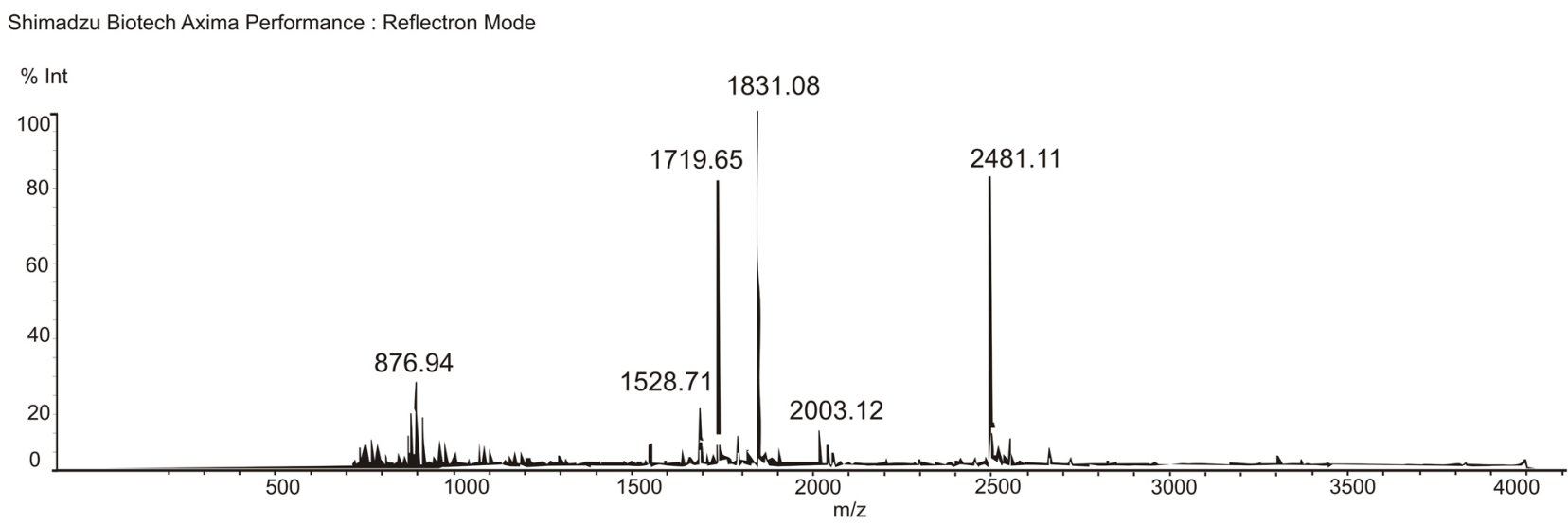

Figure 3. Peptide mass fingerprint spectrum from Matrix Assisted Laser Desorption lonization (MALDI-ToFToF) mass spectrometry (AXIMA Performance ${ }^{\oplus}$, Shimadzu, Japan). Each ion is a peptide fragment from a protein digested with a proteolytic enzyme. 
In addition to analytical equipments, the development of bioinformatics tools was very important to proteomic approach. Several protein profiles were elucidated when these automated database tools identified molecules by means of the genomic information. Besides, proteins can be identified from organisms which genomes were not sequenced. If the genomic information is not available, proteins still might be identified through cross-species protein identification. PMF or MS/MS allow identifying homolog proteins from strongly related species only differ by a few amino acids (12).

Recently, a novel mass spectrometry approach, called matrix-assisted laser desorption-ionization imaging mass spectrometry (MALDI Imaging), was employed in the proteomic strategy. This technology has been used to identify proteins in tissue specimens through direct analysis of histological sections and presents some analytical advantages because of its ability to provide information on the localization and relative abundance of multiple molecules in a sample. The powerful step for this type of analysis is the ability to map the spatial distribution of specific molecular species throughout a tissue section and sequencing the molecular targets at the same time (107). Usually, fresh or formalin-fixed tissue and paraffin-embedded samples can be analyzed by this analytical process. As the molecules must be ionized through a matrix in the MALDI strategy, this matrix can be deposited manually or by a chemical printer in specific points on the tissues.

MALDI imaging mass spectrometry has emerged as a powerful technique for analyzing the spatial arrangement of proteins, peptides, lipids, and small molecules in biological tissues. In a recent publication, a MALDI imaging experiment in rat tissue stung by Apis mellifera was studied (108). This strategy was able to record the distribution of several venom peptides and proteins in envenomed tissue. In the same experiment, they pointed out the appearance of rat peptides and proteins that were previously identified as markers for the inflammatory event evoked by bee venom. Thus, MALDI imaging can assist in the elucidation of many physiological processes in stinging accidents to promote a better understanding of the immune/allergic responses against Hymenoptera venom.

Animal venoms contain highly selective and efficient bioactive molecules that are clinically challenging and scientifically fascinating, which have already led to the development of several new drugs. During billion of years, the nature accumulated and combined powerful libraries of hundreds of thousands of potentially active substances, resulting in useful molecules synthesized from several animal venoms. Bioprospecting activities have improved the identification, collection, cloning and synthesis of new drug candidates for commercial application. Usually, the targets of interest of bioprospecting are purified for further biochemical, enzymatic, functional and structural characterization for the investigation of their structure, functional activities and mechanism of action. Thus, several analytical equipments were developed to provide sensitive analysis with more resolution. Mass spectrometry has become an indispensable proteomic tool to identify the protein expression, protein-protein interactions and posttranslational modifications (1).

\section{CONCLUDING REMARKS}

The bioprospecting of animal venoms reached an important status in the development of drugs for specific treatments or diagnostic tests. The strategy of isolating a natural allergen from Hymenoptera venom and characterize it comprises a biochemical and immunological important task, since it provides the possibility of investigating such allergens and better understanding its structure/activity. Such knowledge will necessarily reveal the level of specificity of this allergen in the immunotherapy process, which will prevent incomplete treatment of a patient and side effects during treatment, including severe anaphylaxis. The understanding of major molecules from Hymenoptera venom is a very important step for future development of new extracts for immunotherapy.

With the new scenario of nanobiotechnology, several animal venom molecules have been revealed through some analytical techniques such as two-dimensional electrophoresis, high performance liquid chromatography and mass spectrometry. New separation techniques are constantly being created with increasing sensitivity and resolution and the development of modern mass spectrometry equipments has promoted an important insight into complex biological samples such as Hymenoptera venom. 
These results were achieved because these new technologies used in the proteomics approaches have high sensitivity and resolution. Besides the improvement of bioinformatics tools for proteomics, databases and formation of human resources have permitted the discovery of numerous animal venom molecules and their biochemical and/or structural characterization.

\section{ACKNOWLEDGEMENTS}

The authors are thankful to FAPESP, CNPq and CAPES for providing financial support.

\section{COPYRIGHT}

(c) CEVAP 2011

\section{SUBMISSION STATUS}

Received: January 12, 2011.

Accepted: April 18, 2011.

Abstract published online: April 26, 2011.

Full paper published online: November 30, 2011.

\section{CONFLICTS OF INTEREST}

There is no conflict.

\section{FINANCIAL SOURCE}

This work was supported by BIOprospecTA/ FAPESP program (process number 06/57122-7), INCT/CNPq and CAPES.

\section{CORRESPONDENCE TO}

LUCILENE DELAZARI DOS SANTOS, CEVAPUNESP, Caixa Postal 577, Fazenda Experimental Lageado, Rua José Barbosa de Barros, 1780, 18610-307, Botucatu, SP, Brasil. Phone: +55 3814 5446. Email: lucilene@cevap.org.br.

\section{REFERENCES}

1. Calvete JJ, Sanz L, Angulo Y, Lomonte B, Gutiérrez JM. Venoms, venomics, antivenomics. FEBS Lett. 2009;583(11):1736-43.

2. Kunin W, Lawton JH. Does biodiversity matter? Evaluating the case for conserving species. In Gaston KJ (Eds). Biodiversity: a biology of numbers and differences. Oxford: Blackwell Science. p. 283-08, 1996.

3. World Resources Institute. World Resources Report 2000-2001. People and ecosystems the fraying web of life. Washington: World Resources Institute; 2000. 389 p.

4. Vetter RS, Visscher PK, Camazine S. Mass envenomations by honey bees and wasps. West J Med. 1999;170(4):223-7.

5. Charpin D, Birnbaum J, Lanteaume A, Vervloet
D. Prevalence of allergy to hymenoptera stings in different samples of the general population. J Allergy Clin Immunol. 1992;90(3 Pt 1):331-4.

6. Souza BM, Mendes MA, Santos LD, Marques MR, César LMM, Almeida RNA, et al. Strutural and funcional characterization of two novel peptide toxins isolated from the venom of the social wasp Polybia paulista. Peptides. 2005;26(11):2157-64.

7. Phillipson JD. Natural products as pharmacological probes and in new pharmaceuticals. The Linnean.1989;5:29-33.

8. Konno K, Hisada M, Itagaki Y, Naoki H, Kawai N, Miwa $\mathrm{A}$, et al. Isolation and structure of pompilidotoxins novel peptide neurotoxins in solitary wasp venoms. Biochem Biophys Res Commun.1998;250(3):612-6.

9. Palma MS. Insect venom peptides. In Kastin A, (Ed). Handbook of Biologically Active Peptides. San Diego: Academy Press. 2006. p. 409-17.

10. Antonicelli L, Bilò MB, Bonifazi F. Epidemiology of hymenoptera allergy. Curr Opin Allergy Clin Immunol. 2002;2(4):341-6.

11. Fitzgerald KT, Flood AA. Hymenoptera stings. Clin Tech Small Anim Pract. 2006;21(4):194-04.

12. De Graaf DC, Aerts M, Danneels E, Devreese B. Bee, wasp and ant venomics pave the way for a component resolved diagnosis of sting allergy. J Proteomics. 2009;72(2):145-54.

13. Nitter-Marszalska M, Liebhart J, Liebhart E, Dor A, Dobek R, Obojski A, et al. Prevalence of Hymenoptera venom allergy and its immunological markers current in adults in Poland. Med Sci Monit. 2004;10(7):324-9.

14. Bilò BM, Rueff F, Mosbech H, Bonifazi F, OudeElberink JNG. Diagnosis of Hymenoptera venom allergy. Allergy. 2005;60(11):1339-49.

15. Castro FFM, Palma MS. Alergia a veneno de insetos. São Paulo: Editora Manole; 2008, p.240.

16. Lima PR de, Brochetto-Braga MR. Hymenoptera venom review focusing on Apis mellifera. J Venom Anim Toxins incl Trop Dis. 2003;9(2):149-62.

17. Saidemberg DM, da Silva-Filho LC, Tognoli LM, Tormena CF, Palma MS. Polybioside, a neuroactive compound from the venom of the social wasp Polybia paulista. J Nat Prod. 2010;73(4):527-31.

18. Mendes MA, Palma MS. Two new bradykinin-related peptides from the venom of the social wasp Protopolybia exigua (Saussure). Peptides. 2006;27(11):2632-9.

19. Pantera B, Hoffman DR, Carresi L, Cappugi G, Turillazzi S, Manao G, et al. Characterization of the major allergens purified from the venom of the paper wasp Polistes gallicus. Biochim Biophys Acta. 2003;1623(2-3):72-81.

20. Hoffman DR. Hymenoptera venom allergens. Clin Rev Allergy Immunol. 2006;30(2):109-28.

21. Habermann E, Neumann WP. Purification of phospholipase A of bee venom. Biochem Z. 1957;328(6):465-73.

22. Hoffman DR, Dove DE, Jacobson RS. Allergens in Hymenoptera venom. XX. Isolation of four allergens from imported fire ant (Solenopsis invicta) venom. J Allergy Clin Immunol. 1988;82(5 Pt.1):818-27.

23. Russo AJ, Cobbs CS, Ishay JS, Calton GJ, Burnett 
JW. Isolation of a lethal factor from venom of Vespa orientalis (oriental hornet) by affinity chromatography using cross reactive monoclonal antibody. Toxicon. 1983;21(1):166-9.

24. Ho CL, Ko JL. Purification and characterization of a lethal protein with phospholipase $\mathrm{A} 1$ activity from the hornet (Vespa basalis) venom. Biochim Biophys Acta. 1988;963(3):414-22.

25. Mueller U, Reisman R, Wypych J, Elliot W, Steger R, Walsh S, et al. Comparison of vespid venoms collected by eletrostimulation and by venom sac extraction. J Allergy Clin Immunol. 1981;68(4):254-61.

26. Hoffman DR, Wood CL. Allergens in Hymenoptera venom XI. Isolation of protein allergens from Vespula maculifrons (yellow jacket) venom. J Allergy Clin Immunol. 1984;74(1):93-103.

27. De Oliveira MR, Palma MS. Polybitoxins: a group of phospholipases A2 from the venom of the neotropical social wasp paulistinha (Polybia paulista). Toxicon. 1988;36(1):189-99.

28. Costa H, Palma MS. Agelotoxin: a phospholipase A2 from the venom of the neotropical social wasp cassununga (Agelaia pallipes pallipes) (HymenopteraVespidae). Toxicon. 2000;38(10):1367-79.

29. Ho CL, Lin YL, Li SF. Three toxins with phospholipase activity isolated from the yellow-legged hornet (Vespa verutina) venom. Toxicon. 1999;37(7):1015-24.

30. Abe T, Sugita M, Fujikura T, Hiyoshi J, Akasu M. Giant hornet (Vespa mandarina) venomous phospholipases. The purification characterization and inhibitory properties by biscloclauine alkaloids. Toxicon. 2000;38(12):1803-16.

31. Hoffman DR. Allergens in Hymenoptera venom XIII: Isolation and purification of protein components from three species of vespid venoms. J Allergy Clin Immunol. 1985;75(5):599-605.

32. Cascone O, Amaral V, Ferrara P, Vita N, Guillemot JC, Díaz LE. Purification and characterization of two forms of antigen 5 from Polybia scutellaris venom. Toxicon. 1995;33(5):659-65.

33. Pirgignani ML, Rivera E, Hellman U, Biscoglio de Jiménez Bonino M. Structural and immunological aspects of Polybia scutellaris Antigem 5. Arch Biochem Biophys. 2002;407(2):224-30.

34. Lu G, Kochoumian L, King TP. Sequence identity and antigenic cross-reactivity of white face hornet venom allergen, also a hyaluronidase, with other proteins. J Biol Chem. 1995;270(9):4457-65.

35. McNairy MM, Gastmeyer J, Pantera B, Hoffman DR. Isolation of paper wasp venom preteases by affinity chromatography. J Allergy Clin Immunol. 2000;105:S57.

36. Hoffman DR, Jacobson RS. Allergens in Hymenoptera venom XXVII: Bumblebee venom allergy and allergens. J Allergy Clin Immunol. 1996;97(3):812-21.

37. Hoffman DR, El-Choufani SE, Smith MM, de Grout $\mathrm{H}$. Occupational allergy to bumblebees: Allergens of Bombus terrestris. J Allergy Clin Immunol. 2001;108(5):855-60.

38. Winningham KM, Fitch CD, Schmidt M, Hoffman DR. Hymenoptera venom protease allergens. J Allergy
Clin Immunol. 2004;114(4):928-33.

39. Schmidt JO. Biochemistry of insect venoms. Ann Rev Entomol.1982, 27:339-68.

40. Wood CL, Hoffman DR. Two-dimensional polyacrylamide gel electrophoresis of hymenoptera venom and venom sac extrats. Toxicon. 1983;21(2):29199.

41. Peiren N, Vanrobaeys F, de Graaf DC, Devreese B, Van Beeumenb J, Jacobs FJ. The protein composition of honeybee venom reconsidered by a proteomic approach. Biochim Biophys Acta. 2005;1752(1):1-5.

42. Honeybee Genome Sequencing Consortium. Insights into social insects from the genome of the honeybee Apis mellifera. Nature. 2006;443(7114):931-49.

43. Peiren N, Graaf DC, Vanrobaeys F, Danneels B, Devreese B, Beeumen JV, et al. Proteomic analysis of the honey bee worker venom gland focusing on the mechanisms of protection against tissue damage. Toxicon. 2008;52(1):72-83.

44. Santos LD, Santos KS, Pinto JR, Dias NB, de Souza $\mathrm{BM}$, dos Santos MF, et al. Profiling the proteome of the venom from the social wasp Polybia paulista: a clue to understand the envenoming mechanism. J Proteome Res. 2010;9(8):3867-77.

45. Galvão CES, Iwai LK, Santos LD, Mendes MA, Palma MS, Castro FFM, et al. Identification of the major allergens of the venom from the South American social wasp Agelaia pallipes. J Allergy Clin Immunol. 2006;117(2):S308.

46. Santos LD, Menegasso ARS, Pinto JR, Santos KS, Castro FFM, Kalil JE, et al. Proteomic characterization of the multiple forms of the PLAs from the venom of the social wasp Polybia paulista. Proteomics. 2011;11(8):1403-12.

47. Moawad TI, Hoffman DR, Zalat S. Isolation, cloning and characterization of Polistes dominulus venom phospholipase A1 and its isoforms. Acta Biol Hung. 2005;56:261-74.

48. Kolarich D, Loos A, Léonard R, Mach L, Marzban $\mathrm{G}$, Hemmer W, et al. A proteomic study of the major allergens from yellow jacket venoms. Proteomics. 2007;7(10):1615-23.

49. Seppälä U, Selby D, Monsalve R, King TP, Ebner C, Roepstorff P, et al. Structural and immunological characterization of the $\mathrm{N}$-glycans from the major yellow allergen Ves v 2: The N-glycan structures are needed for the human antibody recognition. Mol Immunol. 2009;46(10):2014-21.

50. Georgieva D, Greunke K, Betzel C. Three-dimensional model of the honeybee venom allergen Api $m$ 7: structural and functional insights. Mol Biosyst. 2010;6(6):1056-60.

51. Shen LR, Ding MH, Zhang LW, Zhang WG, Liu L, Li D. Expression of a bee venom phospholipase A2 from Apis cerana cerana in the baculovirus-insect cell. J Zhejiang Univ Sci B. 2010;11(5):342-9.

52. Baek JH, Lee SH. Identification and characterization of venom proteins of two solitary wasps, Eumenes pomiformis and Orancistrocerus drewseni. Toxicon. 2010;56(4):554-62. 
53. Baek JH, Woo TH, Kim CB, Park JH, Kim H, Lee S, et al. Differential gene expression profiles in the venom gland/sac of Orancistrocerus drewseni (Hymenoptera: Eumenidae). Arch Insect Biochem Physiol. 2009;71(4):205-22.

54. Hoffman DR, Sakell RH, Schmidt M. Sol i1, the phospholipase allergen of imported fire ant venom. J Allergy Clin Immunol. 2005;115(3):611-6.

55. Chen L, Fadamiro HY. Re-investigation of venom chemistry of Solenopsis fire ants. I. Identification of novel alkaloids in S. richteri. Toxicon. 2009;53(5):46978.

56. Chen L, Fadamiro HY. Re-investigation of venom chemistry of Solenopsis fire ants. II. Identification of novel alkaloids in S. invicta. Toxicon. 2009;53(5):47986.

57. Dohtsu K, Okumura K, Hagiwara K, Palma MS, Nakajima T. Isolation and sequence analysis of peptides from the venom of Protonectarina sylveirae (hymenoptera-vespidae). Nat Toxins. 1993;1(5):271-6.

58. Palma MS. Peptides as toxins/defensins. Amino Acids. 2010;40(1):1-4.

59. Mendes MA, de Souza BM, Palma MS. Structural and biological characterization of three novel mastoparan peptides from the venom of the neotropical social wasp Protopolybia exígua (Saussure). Toxicon. 2005;45(1):101-6.

60. Higashijima T, Burnier J, Ross EM. Regulation of $\mathrm{Gi}$ and Go by mastoparan, related amphiphilic peptides, and hydrophobic amines. Mechanism and structural determinants of activity. J Biol Chem. 1990;265(24):14176-86.

61. Song DL, Chang GD, Ho CL, Chang CH. Structural requirements of mastoparan for activation of membrane-bound guanylate cyclase. Eur J Pharmacol. 1993;247(3):283-8.

62. Jones S, Howl J. Biological applications of the receptor mimetic peptide mastoparan. Curr Protein Pept Sci. 2006;7(6):501-8.

63. de Oliveira L, Cunha AO, Mortari MR, Dos Santos WF. Cataleptic activity of the denatured venom of the social wasp Agelaia vicina (Hymenoptera, Vespidae) in Rattus norvegicus (Rodentia, Muridae). Prog Neuropsychopharmacol Biol Psychiatry. 2006; 30(2):198-203.

64. Murata K, Shinada T, Ohfune Y, Hisada M, Yasuda A, Naoki H, et al. Novel biologically active peptides from the venom of Polistes rothneyi iwatai. Biol Pharm Bull. 2006;29(12):2493-7.

65. Murata K, Shinada T, Ohfune Y, Hisada M, Yasuda A, Naoki $\mathrm{H}$, et al. Novel mastoparan and protonectin analogs isolated from a solitary wasp, Orancistrocerus drewseni drewseni. Amino Acids. 2009;37(2):389-94.

66. Ho CL, Shih YP, Wang KT, Yu HM. Enhancing the hypotensive effect and diminishing the cytolytic activity of hornet mastoparan $\mathrm{B}$ by $\mathrm{D}$-amino acid substitution. Toxicon. 2001;39(10):1561-6.

67. de Souza BM, Marques MR, Tomazela DM, Eberlin MN, Palma MS. Mass spectrometric characterization of two novel inflamatory peptides from the venom of the social wasp Polybia paulista. Rapid Commun Mass
Spectrom. 2004;18(10):1095-102.

68. Mendes MA, Souza BM, Marques MR, Palma MS. Structural and biological characterization of two novel peptides from the neotropical social wasp Agelaia pallipes pallipes. Toxicon. 2004;44(1):67-74.

69. Nakajima T. Pharmacological biochemistry of vespid venoms. In: Piek T( ed). Venom of Hymenoptera. London: Academic Press. p. 309-27, 1986.

70. Rocha T, Leonardo MB, De Souza BM, Palma MS, Da Cruz-Hölfing MA. Mastoparan effects in skeletal muscle damage: An ultrastructural view until now concealed. Microsc Res Tech. 2008;71(3):220-9.

71. Rocha T, de Barros LL, Fontana K, de Souza BM, Palma Ms, da Cruz-Höfling MA. Inflammation and apoptosis induced by mastoparan Polybia-MPII on skeletal muscle. Toxicon. 2010;55(7):1213-21.

72. Sciani JM, Marques-Porto R, Lourenço Junior A, Orsi Rde O, Ferreira Junior RS, Barraviera B, et al. Identification of a novel melittin isoform from Africanized Apis mellifera venom. Peptides. 2010;31(8):1473-9.

73. Matysiak J, Schmelzer CE, Neubert RH, Kokot ZJ. Characterization of honeybee venom by MALDI-TOF and nano ESI-Qq TOF mass spectrometry. J Pharm Biomed Anal. 2011;54(2):273-8.

74. Brigatte P, Cury Y, de Souza BM, Baptista-Saidemberg NB, Saidemberg DM, Gutierrez VP, et al. Hyperalgesic and edematogenic effects of peptides isolated from the venoms of the Apis mellifera and neotropical social wasps Polybia paulista and Protonectarina sylveirae. Amino Acids. 2011;40(1):101-11.

75. Piek T, Spanjer W. Chemistry and pharmacology of solitary wasp venoms. In Piek T (ed) Venoms of the Hymenoptera: Biochemical, Pharmacological and Behavioural Aspects. London: Academic Press. p. 161307, 1986.

76. Eldefrawi AT, Edelfrawi ME, Konno K, Mansour NA, Nakanishi K, Oltz E, et al. Structure and synthesis of a potent glutamate receptor antagonist in wasp venom. Proc Natl Acad Sci USA. 1988;85(13):4910-3.

77. Piek T, Mantel P, Van Ginkel CJ. Megascoliakinin, a bradykinin-like compound in the venom of Megascolia flavifrons Fab. (Hymenoptera: Scoliidae). Comp Biochem Physiol C. 1984;78(2):473-4.

78. Hisada M, Konno K, Itagaki Y, Naoki H, Nakajima T. Advantages of using nested collision induced dissociation/post-source decay with matrix-assisted laser desorption/ionization time-of-flight mass spectrometry: sequencing of novel peptides from wasp venom. Rapid Commun Mass Spectrom. 2000;14(19):1828-34.

79. Konno K, Miwa A, Takayama H, Hisada M, Itagaki Y, Naoki H, et al. Alpha-pompilidotoxin (alpha-PMTX), a novel neurotoxin from the venom of a solitary wasp, facilitates trasmission in the crustacean neuromuscular synapse. Neurosci Lett. 1997;238(3):99-102.

80. Konno K, Hisada M, Naoki H, Itagaki Y, Yasuhara T, Juliano L, et al. Isolation and sequence determination of peptides in the venom of the spider wasp Cyphononyx dorsalis guided by matrix-assited laser desorption/ionization time of flight (MALDI-TOF) 
mass spectrometry. Toxicon. 2001;39(8):1257-60.

81. Konno K, Hisada M, Naori H, Itagaki Y, Kawai N, Miwa A, et al. Structure and biological activities of eumenine mastoparan-AF (EMP-AF), a new mast cell degranulation peptide in the venom of the solitary wasp Anterhynchium flavomarginatum micado. Toxicon. 2000;38(11):1505-15.

82. Konno K, Hisada M, Fontana R, Lorenzi CC, Naoki $\mathrm{H}$, Itagaki $\mathrm{Y}$, et al. Anoplin, a novel antimicrobial peptide from the venom of the solitary wasp Anoplius samariensis. Biochim Biophys Acta. 2001;1550(1):7080.

83. Konno K, Hisada M, Naoki H, Itagaki Y, Fontana R, Rangel $\mathrm{M}$, et al. Eumenitin, a novel antimicrobial peptide from the venom of the solitary eumenine wasp Eumenes rubronotatus. Peptides. 2006;27(11):2624-31.

84. Inagaki H, Akagi M, Imai HT, Taylor RW, Kubo T. Molecular cloning and biological characterization of novel antimicrobial peptides, pilosulin 3 and pilosulin 4, from a species of the Australian an genus Myrmecia. Arch Biochem Biophys. 2004;428(2):170-8.

85. Piek T, Duval A, Hue B, Karst H, Lapied B, Mantel P, et al. Poneratoxin, a novel peptide neurotoxin from the venom of the ant Paraponera clavata. Comp Biochem Physiol C. 1991;99(3):487-95.

86. Orivel J, Redeker V, Le Caer JP, Krier F, Revol-Junelles AM, Longeon A, et al. Ponericins, new antibacterial and insecticidal peptides from the venom of the ant Pachycondylagoeldii.J Biol Chem. 2001;276(21):178239.

87. Phuzhnikov K, Nosyreva E, Shevchenko L, Kokoz Y, Schmalz D, Hucho F, et al. Analysis of ectatomin action on cell membranes. Eur J Biochem. 1999;262(2):501-6.

88. Wiese MD, Chataway TK, Davies NW, Milne RW, Brown SGA, Gal WP, et al. Proteomic analysis of Myrmecia pilosula (jack jumper) ant venom. Toxicon. 2006;47(2):208-17.

89. Son DJ, Kang J, Kim TJ, Song KJ, Yun do Y, Hong JT, et. al. Melitin, a major bioactive component of bee venom toxin, inhibits PDGF receptor beta-tyrosine phosphorylation and downstream intracellular signal transduction in rat aortic vascular smooth muscle cells. J Toxicol Environ Health A. 2007;70(15-16):1350-5.

90. Hisada M, Satake H, Masuda K, Aoyama M, Murata K, Shinada T, et al. Molecular components and toxicity of the venom of the solitary wasp Anoplius samariensis. Biochem Biophys Res Commun. 2005;330(4):1048-54.

91. Murata K, Shinada T, Hanada M, Naoki H, Ohfune Y, Nakajima T. Structure determination of neuroactive compounds from wasp venom; Sample preparation. In: Molecular and Biochemical Approches for Distinguished Insect Ability. "Project 4: Identification, Activity and Mode of Action of Bio-Active Molecules from Blood-Sucking and Stingins Insects". The Annual Meeting on Reasearch for the Future Program. 2001.

92. Mann J. Chemical Aspects of Biosynthesis: Alkaloids. In Oxford Science Publications. New York: Oxford University Press. n. 20. p. 62-80, 1994.
93. Jackson H, Usherwood PN. Spider toxins as tool for dissecting elements of excitatory amino acid transmission. Trends Neurosci. 1988;11(6):278-83.

94. Nakajima T. Biochemistry of vespid venoms. In Tu AT (Org). Insect poisons, allergens, and other invertebrate venoms. Handbook of Natural Toxins. v. 2. p. 109-129, 1984.

95. Evans HE. The evolution of social life in wasps. Proceedings of the $10^{\text {th }}$ International Congress of Entomology. v. 2. p. 449-457, 1958.

96. Evans HE, Eberhard MJW. The wasps. Univ. Michigan Press. Ann Arbor. p. 265, 1970.

97. Schimidt JO. Hymenopteran venoms: Striving toward the ultimate defense against vertebrates. In Insect defenses adaptative mechanisms and strategies of prey and predators. Albany: State University of New York Press. p. 387-419, 1990.

98. Apweiler R, Aslanidis C, Deufel T, Gerstner A, Hansen J, Hochstrasser D, et al. Approaching clinical proteomics: current state and future fields of application in cellular proteomics. Cytometry A. 2009;75(10):816-32.

99. Han X, Aslanian A, Yates JR $3^{\text {rd }}$. Mass spectrometry for proteomics. Curr Opin Chem Biol. 2008;12(5):483-90.

100. Fenn Jb, Mann M, Meng CK, Wong SF, Whitehouse CM. Electrospray ionization for mass spectrometry of large biomolecules. Science. 1989;246(4926):64-71.

101. Karas M, Hillenkamp F. Laser desorption ionization of proteins with molecular masses exceeding 10,000 daltons. Anal Chem. 1988;60(20):2299-301.

102. Görg A, Weiss W, Dunn MJ. Current two-dimensional eletrophoresis technology for proteomics. Proteomics. 2004;4(12):3665-85.

103. Issaq $\mathrm{H}$, Veenstra $\mathrm{T}$. Two-dimensional polyacrylamide gel eletroforesis (2D-PAGE): advances and perspectives. Biotechniques. 2008;44(5):697-8.

104. Perkins DN, Pappin DJ, Creasy DM, Cottrell JS. Probability-based protein identification by searching sequence databases using mass spectrometry data. Eletrophoresis. 1999;20(18):3551-67.

105. Eng JK, McCormack AL, Yates JR. An approach to correlate tandem mass spectral data of peptides with amino acid sequences in a protein database. J Am Soc Mass Spectrom. 1994;5:(11)977-89.

106. Wolters DA, Washburn MP, Yates JR. An automated multidimensional protein identification technology for shotgun proteomics. Anal Chem. 2001;73(23):568390.

107. Chaurand P, Latham JC, Lane KB, Mobley JA, Polosukhin W, Wirth PS, et al. Imaging mass spectrometry of intact proteins from alcoholpreserved tissue speciments: bypassing formalin fixation. J Proteome Res. 2008;7(8):3543-55.

108. Francese S, Lambardi D, Mastrobuoni G, Ia Marca G, Moneti G, Turillazzi S. Detection of honeybee venom in envenomed tissues by direct MALDI MSI. J Am Soc Mass Spectrom. 2009;20(1):112-23. 